\title{
The possibility of implementing solutions for selected sustainable development goals at passenger airports
}

\author{
Joanna $\mathrm{Bąk}^{1, *}$ \\ ${ }^{1}$ CUT Institute of Water Supply and Environmental Engineering, Cracow, Poland
}

\begin{abstract}
Every modern city in the 21 st century should enable its residents to quickly and easily move to other cities within the country, Europe and the world. This is very often implemented through air transport. An inseparable element of this type of conveyance is the presence of facilities such as airports in the vicinity of cities. In 2015, a set of 17 Sustainable Development Goals [1] was established by the United Nations. Their task is, inter alia, environmental protection. These goals should also be taken into account in the management of passenger airports. The article presents a critical review of the feasibility of selected sustainable development goals through solutions in the field of environmental engineering. These include green walls and roofs, the use of renewable energy, and devices that effectively save water and energy. Then, an analysis of the possibilities of their application at passenger airports was carried out. The use of devices increasing the efficiency to achieve sustainable development goals for already implemented solutions was also taken into account. Sometimes a simple and inexpensive investment can significantly improve the quality of natural resources protection.
\end{abstract}

\section{Introduction}

The constant striving to improve, facilitate and increase the comfort of users of all material goods and services offered results in continuous development. However, the progressive development of civilization has an impact on the environment and on human beings. It is for these reasons that the concept of sustainable development was created, assuming that a proper standard of living for contemporary people would be ensured without limiting the chances of future generations to meet their needs. The issues of environmental protection in the 21 st century during the development of so many industries take on even more significance. To intensify the introduction of the idea of sustainable development into reality, the General Assembly of the United Nations in 2015, established 17 goals of sustainable development through its resolution [1]. For each of them, tasks (in the number of 169) were defined for implementation at a specific time, usually until 2030.

\footnotetext{
* Corresponding author: jbak@pk.edu.pl
} 
According to [2], the concept of sustainable development in global terms is a chance for the survival and continuation of the proper development of civilization. For this reason, it is extremely important to use as many opportunities as possible to achieve the goals of sustainable development. It is important not to neglect small or seemingly small-scale solutions, as their multiplication in many objects can bring about significant results.

Airport terminals are not typical public facilities. One of the main characteristics of passenger airports that distinguishes them from other objects is the huge number of users served. The largest European airports serve tens of millions of passengers a year. In 2016, London Heathrow served 75.7 million, the Paris - Charles de Gaulle airport - 65.9 million, and the Amsterdam airport - 63.6 million [3]. In the same year, the largest number of passengers in the world reached Atlanta Airport in the United States - 104.2 million [4]. Other major airports in the world are Beijing (with 94.3 million passengers in 2016) and Dubai with 83.6 million users in the same period [4]. Polish airports, although undoubtedly not among the largest, also serve a significant number of clients. For example, the Warsaw Chopin Airport served 15.752 million passengers in 2017 [5], while the airport at Kraków Balice had 5.835 million travellers in the same period [6]. By averaging these data, it is over 40000 and over 15000 passengers per day respectively, which illustrates the scale of the size and, at the same time, the possibilities. It should be added that airports are developing very dynamically - Warsaw Chopin Airport recorded more than a 22 percent increase in the number of users in 2017 [5]. For these reasons, any airport solution for sustainable development is so important. The aim of the work is to analyse the possibilities of applying solutions serving selected sustainable development goals at passenger airports.

\section{Research methodology}

Sustainable development includes the integration of social, economic and environmental activities. The scope of work includes the analysis of only selected sustainable development goals, especially those related to engineering and environmental protection. In the case of airports, a special document called the Airport Master Plan is preparing whose task it is to support the process of modernization or extension of existing airports, or the construction of completely new facilities.

One of the definitions of this document set by [7] defines its purpose as providing a framework for the development of the airport, inter alia taking into account potential environmental effects. Another document [8] sets out the categories of environmental impact and significance thresholds for airports. Among them, apart from air quality, noise and light emission, there are inter alia natural resources, climate and energy among others. Environmental issues of primary importance are usually dealt with in detail in the Master Plan. There are also special calculation programs for assessing air quality around airports, for example ALAQS (Airport Local Air Quality Studies) [9]. However, with such a large number of passengers served, any solution, including those less important, becomes more important. For this reason, issues of environmental importance were chosen at work, although these are not the most important issues in the case of airports. The sustainable development objectives covered by the analysis at work include:

- ensure access to water and sanitation for all (goal 6)

- ensure access to affordable, reliable, sustainable and modern energy for all (goal 7)

- ensure sustainable consumption and production patterns (goal 12)

- take urgent action to combat climate change and its impacts (goal 13).

Each of the objectives has been analysed separately. The more important advantages and disadvantages of the proposed solutions have been taken into account. The possibilities of implementation and application examples have been indicated for selected tasks. 


\section{Analysis of the possibility of implementing solutions for selected sustainable development goals}

\subsection{Goal 6 Clean water and sanitation}

The issue of access to water of adequate quality is so important that the years 2018 - 2028 were announced by the General Assembly of the United Nations as the International Decade for Action on Water for sustainable development [10]. The goal of 6 out of 17 sustainable development objectives called "clean water and sanitation" includes the task of increasing the efficiency of water use and ensuring sustainable water collection. Airports consume a significant amount of water. To illustrate the situation, it can be stated that the total water intake for the Kraków - Balice airport in 2016 amounted to $69315 \mathrm{~m}^{3}$ with 4.98 million passengers [11], while at the Frankfurt airport in 2013, the drinking water consumption was $1482000 \mathrm{~m}^{3}$ with 58.05 million passengers [12]. Water in airports is consumed in significant quantities in restrooms, as well as in the restaurant zone. In restrooms, water is used for the flushing of toilets and urinals and in the faucets of wash basins.

The simplest and fastest way to reduce water consumption in wash basin faucets in public buildings are flow regulators and aerators. The efficiency of reducing water consumption depends on the solution that is currently used and the one chosen for retrofitting. There are solutions that allow limiting the flow to $1.21 / \mathrm{min}$ [13], and even smaller - $0.1-0.61 /$ minute at atomizers [14]. However, the outflow from the battery should be adapted to the needs of customers. The cost of the regulator is small, but it is worth investing in a housing that makes theft difficult. It is also important to regularly check and possibly clean, otherwise the outflow value may change. The faucets sold today are usually equipped with regulators. These are very popular solutions, so no specific example is given. However, special attention should be paid to the amount of outflow from the faucet.

Electronic faucets are another solution. Efficiency is related to time settings and outflow. The disadvantages are investment costs along with installation costs incomparably greater than in the case of flow regulators. These types of faucets are installed, among others, at the airport John Paul II in Krakow - Balice. Push button faucets can also be used.

Another operation related to water is the flushing of toilets and urinals. For urinals, the most effective solution in this area are waterless urinals. Installation does not require connection to tap water. The downside is the investment costs. The operating costs of the replaceable siphon should be kept in mind. Such solutions have already been applied at Beijing International Airport [15], at Changshui International Airport [16], at Brussels airport [17] and at Frankfurt airport [18].

The offer in the area of economical cisterns is constantly evolving. Currently flush cisterns are available in a two-button system with a smaller flush volume of 2 liters. There are also flush cisterns with electronic actuation combined with manual button that allow flushing. This type of solution is used in toilets at the airport in Krakow - Balice.

Another way to save water when flushing toilets is to use rainwater for this purpose. This solution was used, inter alia, at the Frankfurt airport, where rainwater is used as service water for the flushing of toilets and land irrigation [12].

Another way is integrated sanitary facilities - a washbasin with an urinal or a washbasin with a cistern and toilet. Greywater is used there for flushing. In this case, greywater installation is not needed. They have not yet found a wide application. The issue of hygiene may raise some doubts. 
The Vancouver Airport in Canada, in its strategy for 2015-2019, assumes the analysis of the possibility of obtaining rainwater and reusing greywater to minimize the use of drinking water [19].

An interesting solution offering drinking water for passengers are devices that produce water from air humidity. They can produce almost 200 liters of water per day (depending on the humidity of the air). They can be powered traditionally or from renewable sources [20].

An overview of possible solutions for use in airport restrooms is included in Table 1. Currently, at the airports, sanitary equipment that allows for the effective use of drinking water is often used. In such situations, attention should be paid to two issues. The first one is proper maintenance that allows keeping the assumed parameters of water consumption. The second issue is checking whether currently more efficient sanitary equipment on the commercial market is available.

Table 1. Possibilities to reduce the use of drinking water at airports - advantages and disadvantages.

\begin{tabular}{|c|c|c|}
\hline Proposed solution & Advantages & Disadvantages \\
\hline aerators, flow regulators & $\begin{array}{l}\text { - low price } \\
\text { - easy assembly } \\
\text { - high efficiency } \\
\text { - reduction of water and sewage } \\
\text { bills }\end{array}$ & $\begin{array}{l}\text { - possible necessity to use anti- } \\
\text { vandal housing to eliminate } \\
\text { frequent thefts } \\
\text { - periodic maintenance required } \\
\text { to ensure proper operation }\end{array}$ \\
\hline touchless electronic faucets & $\begin{array}{l}\text { - water saving (depending on } \\
\text { pressure, outflow and time } \\
\text { settings) } \\
\text { - reduction of water and sewage } \\
\text { bills }\end{array}$ & $\begin{array}{l}\text { - investment cost } \\
\text { - operating costs (energy) } \\
\text { - maintenance }\end{array}$ \\
\hline waterless urinals & $\begin{array}{l}\text { - saving } 100 \% \text { of the water used } \\
\text { for urinal flushing (lower charges } \\
\text { for water and sewage) } \\
\text { - possibility of obtaining points } \\
\text { for LEED certificates } \\
\text { - innovation }\end{array}$ & $\begin{array}{l}\text { - investment costs (in the case } \\
\text { of modernization) } \\
\text { - cost of consumables } \\
\text { (replaceable siphons) }\end{array}$ \\
\hline $\begin{array}{l}\text { modern cisterns: } \\
\text { dual flush systems, electronic }\end{array}$ & $\begin{array}{l}\text { - reduction of water consumption } \\
\text { up to } 2 \text { liters / flush in the case of } \\
\text { two - button flushing system } \\
\text { - water saving } \\
\text { - reduction of water and sewage } \\
\text { bills }\end{array}$ & $\begin{array}{l}\text { - investment cost } \\
\text { - periodic replacement of supply } \\
\text { batteries (in the case of } \\
\text { electronic cisterns) } \\
\text { - the problem of a frequent lack } \\
\text { of proper use by users (concerns } \\
\text { dual flush systems) }\end{array}$ \\
\hline use of rainwater & $\begin{array}{l}\text { - possibility of utilizing rainwater } \\
\text { - saving high quality water from } \\
\text { the water supply network } \\
\text { - reduction of fees for water } \\
\text { intake from the water supply } \\
\text { network }\end{array}$ & $\begin{array}{l}\text { - necessary specialist project } \\
\text { with numerous arrangements } \\
\text { - investment cost } \\
\text { - operating costs } \\
\text { - the need to treat rainwater } \\
\text { - the need for additional } \\
\text { metering }\end{array}$ \\
\hline $\begin{array}{l}\text { use of greywater through } \\
\text { integrated sanitary facilities } \\
\text { (without separate installation) }\end{array}$ & $\begin{array}{l}\text { - innovation } \\
\text { - saving water intended for } \\
\text { flushing the urinal / toilet } \\
\text { - reduction of fees for water } \\
\text { intake from the water supply } \\
\text { network and sewage disposal } \\
\text { - space saving }\end{array}$ & $\begin{array}{l}\text { - investment cost } \\
\text { - possible lack of comfort of use }\end{array}$ \\
\hline
\end{tabular}




\begin{tabular}{|c|l|l|}
\hline Proposed solution & \multicolumn{1}{|c|}{ Advantages } & \multicolumn{1}{c|}{ Disadvantages } \\
\hline $\begin{array}{c}\text { generating drinking water } \\
\text { from air humidity }\end{array}$ & $\begin{array}{l}\bullet \text { easy assembly } \\
\bullet \text { innovation } \\
\bullet \text { tap water saving }\end{array}$ & $\begin{array}{l}\bullet \text { investment cost } \\
\text { operating costs (energy) }\end{array}$ \\
\hline
\end{tabular}

\subsection{Goal 7 Affordable and clean energy}

Goal 7 is clean and available energy. Among the tasks set out for this purpose is to increase the share of renewable sources. There are many solutions and they are still coming. Among the more interesting proposals, solar benches for charging mobile devices or obtaining information may be mentioned. Krakow airport is in the process of introducing such a solution [6]. The power of solar panels installed in such benches ranges from 60 to 120 $\mathrm{W}$. Most types are adapted to work in the temperature range from -20 to $50^{\circ} \mathrm{C}$. The charging of devices can be done via USB or inductively [21]. An important advantage of such benches is the acquisition of solar energy thanks to them. Another interesting example is the Cochin airport in India, which is the first in the world to operate completely using solar energy. The project started with the installation of 400 solar panels in 2013, and currently there are more than 46000 [22]. In the case of solutions using renewable energy (solar energy, wind energy), it should be remembered that it cannot be used effectively everywhere, therefore the possibility of its use is limited. The use of modern LED lighting or effective hand dryers in restrooms allow increasing the efficiency of energy consumption.

\subsection{Goal 12 Responsible consumption and production}

Goal 12 is responsible consumption and production. This issue is a very broad topic. Within the scope of the task regarding the effective use of natural resources, the proposed solutions for the use of water can be repeated here. The same applies to the efficient use of energy. It can be added that reducing water consumption in wash basins also reduces the energy consumption for heating water.

Biophilic design assuming, among other things, the provision of the greatest possible access to natural lighting [23] used in terminals also correlates with the reduction of energy consumption. This objective also includes the task of minimizing waste generation, including through recycling. Selective waste collection has already been implemented at airports for a long time. The effectiveness of this collection can be constantly increased. Many airports are considering or deciding to compost waste [e.g. 24]. A good example of recycling can be the Wellington airport in New Zealand. Since 2018 coffee grounds from the airport every week are directed to a non-profit organization for processing them into compost. The annual amount of coffee grounds generated at this airport is 18 tons [25]. Many good waste management practices from airports are described in [26]. An example of these is the composting program for food waste from the San Francisco airport.

\subsection{Goal 13 Climate action}

Objective 13 covers climate action. Like the previous goal, it takes into account many different activities. Of the many possibilities, the creation of green roofs and green walls within the airport were chosen. Green roofs on buildings can be treated as an action for adaptation to climate change. They support the management of rainwater, and in the case of a large number of them, they offset the effect of the urban heat island. In addition, they reduce the energy costs for air conditioning in the summer and heating costs in the winter. 
In addition to the advantages of green roofs, they have some drawbacks. These include high investment costs, the need for care (in the case of extensive roofs mainly at the beginning of their operation). It is also important to ensure the quality of their construction and materials. There is another very important aspect at facilities such as airports - namely the possibility of attracting wild birds so dangerous to aviation. Studies carried out by [27] on the roof planted with Sedum spp. showed that it did not attract wild animals or increase the risk of bird attacks. The use of the green roof by the birds was small and appeared to be similar to the use of neighbouring buildings covered with traditional roofs. One should bear in mind the possibility of attracting birds and very carefully choose the vegetation on the green roof.

Despite the potential problems with birds, many airports have decided to introduce green roofs on some of their facilities. These include, among others, airports in Germany (Stuttgart, Munich, Bremen), the Netherlands, Switzerland, Italy, France [28] and Poland (Katowice - Pyrzowice) [29].

The associated issue is the use of green walls, although also in this case the possibility of attracting birds should be considered. They usually require irrigation, and their participation in the management of rainwater is much smaller than green roofs.

\section{Summation and conclusions}

There are many opportunities to achieve the goals of sustainable development, and the innovative industry means that more and more of them are coming each year. In order to fully implement the ideas and principles of sustainable development, it is advisable that all the possibilities of achieving sustainable development goals in the plans for construction and modernization are taken into account at the airports. In the case of airports, even a seemingly insignificant solution taking into account the number of passengers can give impressive results.

In addition to the introduction of solutions that meet the goals of sustainable development, their subsequent proper operation is also important. The maintenance of faucets, flush cisterns or aerators and the proper care of green roofs is very important. Even the best solutions in the absence of supervision and control may not bring the expected results.

\section{References}

1. General Assembly of the United Nations, Transforming our world: the 2030 Agenda for Sustainable Development, A/RES/70/1

2. A. Skowroński, Problems of Sustainable Development, 1, no 2, p. 45 - 57 (2006)

3. M. Januszek, https://inzynieria.com/wpis-branzy/rankingi/10/48570, najwiekszeeuropejskie-lotniska-2017, access 30.04.2018

4. M. Piotrowski, https://www.fly4free.pl/najwieksze-lotnisko-swiata-obsluzylo-ponad104-mln-pasazerow-ale-wkrotce-moze-zostac-zdetronizowane, (2017)

5. https://www.lotnisko-chopina.pl

6. http://www.krakowairport.pl

7. FAA Advisory Circular 150/5070-6B, Change: 2 (2015)

8. FAA Order 1050.1F Environmental Impacts: Policies and Procedures (2015)

9. M. Jeż, Prace Instytutu Lotnictwa, 206, p. 59 - 71

10. http://www.unesco.org

11. Report of sustainable development, Kraków Airport (2016) 
12. Fraport, Environmental Statement (2014)

13. http://www.savinga.pl

14. http://www.neoperl.net

15. https://www.waterlesscartridges.co.uk/4/Falcon-Velocity-Waterless-Cartridges-About

16. http://falconwaterfree.com/changshui-international-airport-selects-falcon-waterfreeurinals

17. https://www.brusselsairport.be

18. I. Carvalho, M.L. Calijuri, P. Assemany, M. Dornelas Freitas Machado e Silva, R. Fernandes Moreira Neto, A. Santiago, M. Souza, Resources, Conservation and Recycling, 74, p. $27-36$ (2013)

19. 2015 - 2019 Environmental Management Plan, Vancouver Airport Authority (2014)

20. http://www.drinkableair.com

21. https://seedia.city/pl

22. https://www.cochinairport.com

23. S. Kellert, Dimensions, elements, and attributes of biophilic design. Biophilic Design. 3-20, (2008)

24. https://www.ajc.com/business/hartsfield-jackson-chooses-firm-develop-recyclingfacility

25. Wellington Airport coffee grounds to be recycled into premium compost, Airport news \& updates, https://www.wellingtonairport.co.nz (2018)

26. FAA, Recycling, Reuse an Waste Reduction at Airports: A synthesis document (2013)

27. R.M. Swearingin, C. Pullins, T. Guerrant, B.E. Washburn, Green Roofs in the Airport Environment: Pleasant Dreams or Nightmares?, Abstract of poster presentation at Bird Strike Committee USA/Canada Meeting, Lake Mary and Sanford, Florida, August 1821, (2008)

28. L.S. Velazquez, European airport greenroofs - a potential model for North America, http://www.greenroofs.com (2008)

29. http://www.matchembud.com.pl 